\title{
Jurist-Diction
}

Volume 3 No. 6, November 2020

\section{Pelarangan Buku Pasca Putusan Mahkamah Konstitusi Nomor 6-13-20/PUU-VIII/2010}

\author{
Dwi Prasetyo \\ dwi.prasetyo-2014@fh.unair.ac.id \\ Universitas Airlangga
}

How to cite:

Dwi Prasetyo, 'Pelarangan

Buku Pasca Putusan

Mahkamah Konstitusi Nomor

6-13-20/PUU-VIII/2010'

(2020) Vol. 3 No. 6 November

Jurist-Diction.

Histori artikel:

Submit 6 Agustus 2020;

Diterima 7September 2020;

Diterbitkan 1 November 2020.

DOI:

10.20473/jd.v3i6.22966

\begin{abstract}
Abstrak
Tulisan ini membahas tentang pelarangan buku di Indonesia pasca putusan Mahkamah Konstitusi Nomor 6-13-20/PUU-VIII/2010. Putusan Mahkamah tersebut berakibat Undang-Undang Nomor 4/ PNPS/1963 bertentangan dengan Undang-Undang Dasar Negara Republik Indonesia Tahun 1945. Putusan tersebut memberikan petunjuk bahwa mekanisme pelarangan buku harus melalui putusan peradilan yang memperoleh kekuatan hukum tetap. Masih banyak pihak yang belum memahami bagaimana standar hukum hak asasi manusia berpengaruh terhadap pengaturan perbukuan. Skripsi ini ditulis dengan metode penelitian normatif menggunakan pendekatan perundang-undangan, pendekatan konsep, dan pendekatan kasus untuk menganalisis permasalahan hukum yang diangkat. Dari penelitian yang penulis lakukan diperoleh hasil bahwa pelarangan buku hanya dapat dilakukan sesuai dengan peraturan perundang-undangan yang berlaku. Pengaturan pelarangan buku di Indonesia telah sesuai dengan standar hak asasi manusia. Pelarangan buku sebagai salah satu sarana kebebasan ekspresi haus dilaksanakan dengan prinsip negara hukum dan demokrasi.

Kata Kunci: Buku; Mahkamah Konstitusi; Hak Asasi Manusia
\end{abstract}

\section{Pendahuluan}

Kepolisian Sektor Kraksaan Kabupaten Probolinggo Jawa Timur memeriksa dua orang anggota Komunitas Vespa Literasi pada 27 Juni 2019. Keduanya membuka lapak membaca gratis di Alun-alun Kota Kraksaan. Mereka diduga menyediakan buku-buku bacaan tentang Partai Komunis Indonesia. Polisi kemudian mengamankan beberapa buku bacaan terkait dengan pimpinan Partai Komunis Indonesia yaitu Dipa Nusantara Aidit. Judul buku yang diamankan adalah Aidit Dua Wajah Dipa Nusantara, Menempuh Di Jalan Rakjat D.N Aidit, Sukarno 
Marxisme \& Leninisme, dan D N Aidit Sebuah Biografi Ringkas. ${ }^{1}$

Di Kota Makassar Sulawesi Selatan, sekelompok Massa yang mengatasnamakan Brigade Muslim Indonesia (BMI) datang ke toko buku dan memeriksa buku-buku berpaham Marxisme dan Komunisme. Mereka kemudian meminta toko buku tersebut untuk menarik buku-buku tersebut dari peredaran dan mengembalikannya pada penerbit karena dilarang Undang-Undang. Beberapa judul buku yang mereka periksa diantaranya Dalam Bayang-Bayang Lenin, Pemikiran Karl Marx dan Tokoh-Tokoh Dunia yang Mempengaruhi Pemikiran Bung karno. Video mereka viral di media sosial pada 3 Agustus 2019. Di dalam video itu seorang pria mengatakan bahwa Kota Makassar harus bebas paham-paham Marxisme dan paham-paham Leninisme. ${ }^{2}$

Praktik pelarangan buku dengan aksi razia dan penyitaan buku yang dilakukan oleh aparat Kepolisian Republik Indonesia, Tentara Nasional Indonesia, Kejaksaan Republik Indonesia, maupun Organisasi Masyarakat terus terjadi. Mereka melakukannya karena menganggap bahwa buku terkait Komunisme/MarxismeLeninisme harus dilarang karena berisikan paham berbahaya. Buku-buku yang berisi tentang ajaran Komunisme/Marxisme-Leninisme menurut mereka harus ditarik dari peredaran karena melanggar hukum.

Berdasarkan putusan Mahkamah Konstitusi Nomor 6-13-20/PUU-VIII/2010 mekanisme pelarangan buku diharuskan melalui proses pengadilan atau harus sesuai dengan Kitab Undang-undang Hukum Acara Pidana (KUHAP) apabila dilakukan penyitaan. Pelarangan buku dengan razia, penyitaan atau pengamanan, dan pembubaran diskusi buku adalah tindakan yang tidak sesuai Undang-Undang Dasar Negara Republik Indonesia Tahun 1945. Tindakan anggota Kepolisian, Kejaksaan, dan TNI serta Ormas yang menyita buku langsung dari toko buku

\footnotetext{
1 M. Rofiq, 'Sediakan Buku Berbau PKI, Dua Pemuda di Probolinggo diamankan', $<$ https://news.detik.com/berita-jawa-timur/d-4643537/sediakan-buku-berbau-pki-dua-pemuda-diprobolinggo-diamankan>, accessed 10 Agustus 2019.

2 Didit Hariyadi, 'Brigade Muslim Indonesia: Tak Ada Razia Buku di Gramedia', <https:// nasional.tempo.co/read/1232103/brigade-muslim-indonesia-tak-ada-razia-buku-di-gramedia $>$, accessed 10 Agustus 2019.
} 
atau masyarakat adalah bertentangan dengan prinsip negara hukum yang dianut negara Indonesia.

Sebagai salah satu media cetak, buku telah lama dikenal terlebih dahulu sebelum surat kabar atau majalah. Buku merupakan salah satu media cetak yang digunakan untuk menuangkan buah pikiran telah dikenal sejak zaman kuno. Di dalam buku terekam ekspresi dan pendapat yang dinyatakan dalam bentuk tulisan hingga menjadi gagasan. Ketika pelarangan peredaran buku dilakukan, kebebasan berekspresi dan menyatakan pendapat turut diciderai.3 Tentunya pelarangan buku yang tidak sesuai dengan mekanisme peraturan perundang-undangan atau putusan pengadilan adalah pelanggaran terhadap Hak Asasi Manusia.

Tersedianya buku yang berkualitas dapat meningkatkan budaya literasi sehingga masyarakat mampu meningkatkan kualitas hidup serta mendorong peranan dalam global seperti dalam kegiatan sosial perdamaian dunia dan perdagangan atau ekonomi internasional. Berbagai peristiwa razia, penyitaan atau pengamanan buku, dan pembubaran diskusi buku tersebut akan menghambat negara untuk mencapai tujuan. Pemerintah dan Dewan Perwakilan Rakyat telah mengesahkan UndangUndang Nomor 3 tahun 2017 tentang Sistem Perbukuan. Dengan Undang-Undang ini telah ada jaminan bahwa negara telah bertanggung jawab terhadap masalahmasalah perbukuan di Indonesia

\section{Metode Penelitian}

Tipe penelitian yang digunakan dalam penulisan ini adalah penelitian hukum. Penelitian hukum (legal research) adalah suatu proses untuk menemukan aturan hukum, prinsip-prinsip hukum, maupun doktrin-doktrin hukum guna menjawab isu hukum yang dihadapi. ${ }^{4}$ Pendekatan yang digunakan dalam penulisan skripsi ini adalah pendekatan perundang-undangan (statute approach), pendekatan konseptual (conceptual approach), pendekatan kasus (case approach).

\footnotetext{
3 Selma Theofany, 'Negara di Tengah Penghancuran Literasi', (Kompas, 23 Agustus 2019), [VI].

4 Peter Mahmud Marzuki, Penelitian Hukum (Kencana Prenada Media Group 2009).[35].
} 
Pendekatan perundang-undangan (Statute approach) yaitu dilakukan dengan menelaah semua undang-undang dan regulasi yang bersangkut paut dengan isu hukum yang sedang ditangani. ${ }^{5}$ Penggunaan pendekatan ini digunakan untuk mencari hal-hal berkaitan dengan peraturan perundang-undangan atau regulasi yang menyangkut pelarangan buku di Indonesia.

Pendekatan konseptual (conceptual approach) yaitu pendekatan yang beranjak dari pandangan-pandangan dan doktrin-doktrin yang berkembang di dalam ilmu hukum, dengan mempelajari hal tersebut penulis akan menemukan ide-ide yang melahirkan pengertian-pengertian hukum, konsep-konsep hukum, dan asas-asas hukum yang relevan dengan isu hukum yang diangkat. ${ }^{6}$ Pendekatan ini digunakan untuk menelaah konsep-konsep di dalam hukum berkaitan pertimbangan dalam putusan Mahkamah Konstitusi.

Selain itu juga pendekatan yang digunakan dalam penulisan ini adalah pendekatan kasus (case approach) yaitu Putusan Mahkamah Konstitusi Nomor 6-13-20/PUU-VII/2010. Yang menjadi kajian pokok di dalam pendekatan kasus adalah ratio decidendi atau reasoning yaitu pertimbangan Mahkamah Konstitusi untuk sampai pada suatu putusan. ${ }^{7}$

\section{Pertimbangan Hukum Putusan Mahkamah Konstitusi Nomor 6-13-20/PUU- VIII/2010}

Putusan Mahkamah Konstitusi Nomor 6-13-20/PUU-VIII/2010 adalah putusan mengenai pengujian Undang-Undang terhadap Undang-Undang Dasar 1945 yaitu para pemohon memohonkan pengujian Undang-Undang Nomor 16 Tahun 2004 tentang Kejaksaan Republik Indonesia dan Undang-Undang Nomor 4/PNPS/1963 tentang Pengamanan Terhadap Barang-Barang Cetakan Yang Isinya Dapat Mengganggu Ketertiban Umum yang telah disahkan oleh Undang-Undang Nomor 5 Tahun 1969 tentang Pernyataan Berbagai Penetapan Presiden dan Peraturan

\footnotetext{
ibid.[93].

6 ibid.[95].

7 ibid.[94].
} 
Presiden Sebagai Undang-Undang. Putusan ini dibacakan dalam sidang pleno Mahkamah Konstitusi pada hari Rabu tanggal tiga belas bulan Oktober tahun 2010. Pasal-pasal dalam UU 4/PNPS/1963 pada pokoknya memberikan kewenangan kepada Jaksa Agung untuk melarang dan menyita barang cetakan yang isinya dapat mengganggu ketertiban umum.

Pasal-pasal yang dimohonkan kepada Mahkamah Konstitusi yaitu pasal 30 ayat (3) huruf c Undang-Undang Nomor 16 Tahun 2004 tentang Kejaksaan Republik Indonesia yang mengatur bahwa, ..."Dalam bidang ketertiban dan ketentraman umum, kejaksaan turut menyelenggarakan: a..., b..., c. Pengawasan barang cetakan” dan memohonkan pengujian Undang-Undang Nomor 4/PNPS/1963 tentang Pengawasan Terhadap Barang Cetakan yang Isinya Dapat Menggagu Ketertiban Umum. Pemohon dalam Permohonan Nomor 6/PUU-VIII/2010 memohon pengujian Pasal 1 seluruhnya dan Pasal 6, para pemohon Permohonan Nomor 13/PUU-VIII/2010 memohonkan pengujian Pasal 1 sampai dengan Pasal 9, dan para Pemohon Nomor 20/PUU-VIII/2010 memohon pengujian formil terhadap Undang-Undang Nomor 4/PNPS/1963.

Putusan Mahkamah Konstitusi Nomor 6-13-20/PUU-VIII/2010 memuat keseluruhan isi permohonan oleh para pemohon disertai dengan alasan-alasan para pemohon. Putusan tersebut juga memuat keterangan ahli dari masing-masing pemohon. Selain itu juga dimuat keterangan dari pihak-pihak terkait yaitu Kejaksaan Agung, Pemerintah, dan Dewan Perwakilan Rakyat. Dalam putusan tersebut ternyata suara Hakim Konstitusi tidak bulat. Seorang hakim Konstitusi yaitu Hamdan Zoelva memiliki pendapat berbeda (dissenting opinion). Dissenting opinion adalah pendapat yang berbeda secara substantif sehingga menghasilkan amar yang berbeda.

Penulis akan berfokus kepada pertimbangan hukum Mahkamah Konstitusi dalam pokok permohonan. Terkait dengan kewenangan Mahkamah serta kedudukan hukum pemohon (legal standing) Mahkamah menilai berwenang dan berdasarkan dalilnya para pemohon mempunyai kedudukan hukum. Dalam pendapat hukumnya Mahkamah mempertimbangkan terlebih dahulu pengujian formil atas Undang-Undang nomor 4/PNPS/1963. Pengujian formil yaitu pengujian terhadap 
terbentuknya Penetapan Presiden Nomor 4 Tahun 1963 tentang Pengamanan Terhadap Barang-barang Cetakan yang Isinya Dapat Mengganggu ketertiban Umum. Pengujian formil adalah pengujian Undang-Undang yang berkenaan dengan proses pembentukan Undang-Undang dan hal-hal lain yang tidak termasuk pengujian materiil. ${ }^{8}$ Jika dilihat antara pengujian formil dan materiil, yang paling besar konsekuensinya adalah undang-undang yang terbukti cacat formil, karena dengan dikabulkannya pengujian formil atas suatu undang-undang maka akan berdampak pada pembatalan sebuah undang-undang secara keseluruhan. ${ }^{9}$

Pengujian formil terhadap UU 4/PNPS/1963 adalah termasuk pengujian terhadap Penetapan Presiden Nomor 4 tahun 1963 tentang Pengamanan Terhadap Barang Cetakan-barang Cetakan yang Isinya Dapat mengganggu ketertiban umum (Lembaran Negara Republik Indonesia Tahun 1963 Nomor 23, Tambahan Lembaran Republik Indonesia Nomor 2533). Mahkamah melihat proses pembentukannya Penetapan Presiden Nomor 4 tahun 1963 sudah sesuai dengan prosedur sesuai Surat Presiden Republik Indonesia Nomor 2252/HK/59 tentang Bentuk PeraturanPeraturan Negara, tertanggal 20 Agustus 1959, yang dikirimkan Presiden Soekarno kepada Ketua Dewan Perwakilan Rakyat dimana di dalamnya mengatur bahwa peraturan Presiden menjadi salah satu peraturan negara lainnya untuk melaksanakan Dekrit Presiden. Demikian Mahkamah dalam putusannya menyatakan:

"Bahwa jika pengujian secara formil terhadap Undang-Undang a quo yang dipermasalahkan, memang melihat adanya suatu ketidak sesuaian dengan proses pembentukan Undang-Undang pada umumnya, oleh karena Undang-Undang a quo berasal dari penetapan presiden yang dibentuk oleh presiden sendiri tanpa melibatkan Dewan Perwakilan Rakyat. Selain itu, Penetapan Presiden Nomor 4 Tahun 1963 tentang Pengamanan Terhadap Barang Cetakan yang Isinya Dapat Mengganggu Ketertiban Umum dibentuk sebelum adanya Perubahan UUD 1945 sehingga tata cara pembentukannya tentu berbeda dengan pembentukan Undang-Undang setelah berlakunya Perubahan UUD 1945”.

\footnotetext{
8 Peraturan Mahkamah Konstitusi Nomor 6/PMK/2005 tentang Pedoman Beracara Dalam Perkara Pengujian Undang-Undang.

9 Jorawati Simarta, 'Pengujian Undang-undang Secara Formil oleh Mahkamah Konstitusi: apakah Keniscayaan? (Perbandingan Putusan Mahkamah Konstitusi Nomor 79/PUU-XII/2014 dan Putusan Mahkamah Konstitusi Nomor 27/PUU-VII/2009)' (2017) 14 Jurnal Legislasi Indonesia. [40].
} 
Mahkamah selanjutnya berkesimpulan bahwa oleh karena peraturan tersebut dibuat pejabat yang berwenang UU 4/PNPS/1963 adalah peraturan yang secara formal sah dan mempunyai daya laku (validity) mengikat umum, walaupun secara material isi atau substansinya dapat diajukan pengujiannya.

Tetapi dalam pertimbangan hukum selanjutnya Mahkamah merujuk pada putusan terdahulu yaitu putusan Nomor 27/PUU-VII/2009 yang memberikan batasan waktu pengujian formil Undang-Undang. Mahkamah menyatakan:

"Bahwa karakteristik pengujian formil berbeda dengan pengujian materiil, sehingga menurut Mahkamah terhadap pengujian secara formil perlu diberikan pembatasan waktu dalam hal pengajuannya, agar terdapat kepastian hukum, oleh karena pengujian secara formil dapat menyebabkan suatu Undang-Undang dinyatakan batal sejak dari awal. Terhadap jangka waktu permohonan pengujian secara formil, Mahkamah dalam putusanya Nomor 27/PUU-VII/2009 tanggal 16 Juni 2010 telah memberikan batasan yaitu, 45 (empat puluh lima) hari setelah Undang-Undang dimuat dalam Lembaran Negara sebagai tenggat yang memadai”.

Dengan merujuk putusan Mahkamah Konstitusi tersebut pengujian formil para pemohon telah melewati batas waktu sehingga dinyatakan tidak dapat diterima.

Dalam pertimbangan hukumnya Mahkamah bisa saja langsung merujuk kepada putusan terdahulu saat memeriksa pengujian formil tetapi itu tidak dilakukan. Mahkamah tetap menggali lebih dalam dengan melihat latarbelakang adanya suatu Undang-Undang yang di uji. Penafsiran tersebut menggunakan metode penafsiran historis dalam arti luas. Mahkamah tetap menelusuri sejarah pembentukan UU 4/ PNPS/1963 dikaitkan dengan hukum-hukum pada masa itu beserta sistem hukum yang berlaku. Jika dikaitkan dengan model-model penalaran hukum penulis melihat bahwa dalam mempertimbangkan pengujian formil Mahkamah menggunakan positivisme hukum. Positivisme hukum yaitu dengan memperhatikan legitimasi peraturan dan tetap menggunakan norma-norma hukum sebagai acuan. ${ }^{10}$

Mengenai pengujian materiil, permohonan Nomor 13/PUU-VIII/2010 telah mencakup dua permohonan lain karena memohonkan pengujian Pasal 1 sampai

\footnotetext{
2009).[246].

${ }^{10}$ Shidarta, Karakteristik Penalaran Hukum Dalam Konteks KeIndonesiaan (CV. Utomo
} 
9 Undang-Undang Nomor 4/PNPS/1963. Di awal Mahkamah memberikan pertimbangan sebagai berikut:

"Bahwa dalam suatu negara hukum seperti Indonesia, mutlak adanya due process of law yaitu penegakan hukum dalam suatu sistem peradilan. Apabila ada suatu perbuatan dikategorikan sebagai perbuatan melawan hukum maka prosesnya harus melalui putusan pengadilan sehingga pelarangan peredaran suatu barang, misalnya barang yang dapat mengganggu ketertiban umum tidak dapat diserahkan kepada suatu instansi tanpa melalui proses putusan pengadilan.

Kewenangan Jaksa Agung melarang peredaran barang cetakan in casu buku tanpa melalui proses peradilan merupakan salah satu pendekatan negara kekuasaan, bukan negara hukum seperti Indonesia sebagaimana yang ditegaskan dalam Pasal 1 ayat (3) UUD 1945 bahwa negara Indonesia adalah negara hukum".

Pertimbangan hukum oleh Mahkamah tersebut adalah sesuai dengan Pasal 28D ayat (1) UUD NRI 1945 yang menyatakan bahwa, setiap orang berhak atas pengakuan, jaminan, perlindungan, dan kepastian hukum yang adil serta perlakuan yang sama di hadapan hukum. Di dalam pasal ini menunjukkan dua asas penting, yaitu proses hukum yang adil (due process of law) dan asas perlakuan yang sama depan hukum. ${ }^{11}$ Menurut pendapat penulis terjaminnya dua asas tersebut adalah penting demi mewujudkan terpenuhinya hak asasi manusia. Penulis akan membahasnya dalam sub-bab tersendiri di bab tiga.

Pertimbangan hukum selanjutnya, Mahkamah memberikan contoh pendekatan negara kekuasaan dalam sejarah Indonesia. Berikut pernyataannya:

"Lebih dari sekadar menyita suatu barang, dahulu Pemerintah dapat membubarkan suatu partai politik tanpa melalui proses peradilan, yang kemudian hal semacam itu ditiadakan dengan perubahan UUD 1945 yang dalam Pasal 24C ayat (1) UUD 1945 menentukan bahwa pembubaran partai politik menjadi salah satu kewenangan Mahkamah Konstitusi.

Pendekatan kekuasaan juga dahulu dilakukan dalam penjatuhan Presiden. Almarhum Presiden Soekarno, Presiden Soeharto dan Presiden Abdurrahman Wahid dijatuhkan dari jabatan tanpa melalui proses peradilan. Setelah perubahan UUD 1945, Pasal 7A dan Pasal 7B telah mengatur mekanisme dan prosedur pemberhentian Presiden dan/atau Wakil Presiden dalam masa jabatannya yang harus melalui proses peradilan dalam hal ini melalui

\footnotetext{
${ }^{11}$ Mahrus Ali, 'Pengawasan Peredaran Barang Cetakan, Due Process of Law dan Hak Atas Kebebasan Berpendapat' (2011) 8 Jurnal Konstitusi.[526].
} 
Mahkamah Konstitusi dengan hukum acara yang diatur dalam Pasal 80 sampai dengan Pasal 85 Undang-Undang Nomor 24 Tahun 2003 tentang Mahkamah Konstitusi”.

Pertimbangan tersebut menunjukkan bahwa Indonesia pernah menerapkan pendekatan kekuasaan dalam penyelenggaraan negara. Kewenangan pembubaran partai oleh pemerintah Indonesia dahulu memberikan kekuasan yang terlalu besar kepada eksekutif. Pernyataan tersebut juga menunjukkan secara langsung bahwa Mahkamah Konstitusi sebagai suatu kekuasaan kehakiman yang dapat menjamin keadilan sebagai upaya untuk mewujudkan Indonesia sebagai negara hukum yang demokratis dan sekaligus negara demokrasi yang berdasar atas hukum. ${ }^{12}$

Mahkamah lebih lanjut menegaskan bahwa tindakan penyitaan barang tersebut melanggar peraturan perundang-undangan dan bertentangan UndangUndang Dasar. Pernyataan Mahkamah sebagai berikut:

"Bahwa demikian pula penyitaan barang-barang cetakan yang dilakukan oleh Kejaksaan, Kepolisian, dan alat negara lain yang mempunyai wewenang memelihara ketertiban umum, sebagaimana ketentuan Pasal 6 UndangUndang Nomor 4/PNPS/1963, tanpa izin dari ketua pengadilan negeri setempat, merupakan suatu ketentuan yang bertentangan dengan Pasal 38 ayat (1) Undang-undang Nomor 8 Tahun 1981 tentang Hukum Acara Pidana (KUHAP) yang menegaskan, "Penyitaan hanya dapat dilakukan oleh penyidik dengan surat izin dari ketua pengadilan negeri setempat", sehingga antara ketentuan Pasal 6 UU Nomor 4/PNPS/1963 dan Undang-undang Nomor 8 Tahun 1981 tentang Hukum Acara Pidana menimbulkan ketidakpastian hukum yang melanggar ketentuan Pasal 28D ayat (1) UUD 1945 yang menegaskan, "Setiap orang berhak atas pengakuan, jaminan, perlindungan, dan kepastian hukum yang adil serta perlakuan yang sama di hadapan hukum".

Demikian Mahkamah menunjukkan bahwa tidak ada kesesuaian antara UU 4/ PNPS/1963 dengan KUHAP. Selain melanggar UUD 1945 ketidak sesuaian tersebut tentu akan membingungkan masyarakat. Konflik antar norma seperti ini dapat dihadapi dengan menggunakan asas preferensi yaitu lex posterior derogate legi priori, yaitu peraturan yang perundang-undangan yang ada kemudian

${ }_{12}$ I D G. Palguna, Mahkamah Konstitusi Dalam Transisi Demokrasi, Konstitusi dan Ketatanegaraan Indonesia Kontemporer (The Biography Institute 2007).[389]. 
mengalahkan peraturan perundang-undangan terdahulu. ${ }^{13}$ Ketentuan KUHAP adalah peraturan baru yang dapat mengalahkan ketentuan dalam UU 4/PNPS/1963. Tentu pemerintah tidak boleh membiarkan keadaan ini terus berlanjut, masyarakat membutuhkan kepastian agar mereka dapat melaksanakan kewajiban dan hak-hak mereka terpenuhi.

Selanjutnya Mahkamah kembali menegaskan bahwa penyitaan secara langsung adalah pelanggaran Undang-Undang Dasar dalam hal ini adalah hak milik pribadi. Berikut bertimbangan hukum Mahkamah.

"Penyitaan buku-buku sebagai salah satu barang cetakan tanpa melalui proses peradilan, sama dengan pengambilan hak milik pribadi secara sewenangwenang yang amat dilarang oleh Pasal 28H ayat (4) UUD 1945 yang menegaskan, "Setiap orang berhak mempunyai hak milik pribadi dan hak milik tersebut tidak boleh diambil alih secara sewenang-wenang oleh siapa pun". Tindakan pengambilalihan barang cetakan tanpa prosedur yang benar menurut hukum, terutama tanpa melalui proses peradilan, merupakan suatu eksekusi tanpa peradilan (extra judicial execution) yang sangat ditentang dalam suatu negara hukum yang menghendaki due process of law. Due process of law, seperti yang dipertimbangkan diatas, adalah penegakan hukum melalui suatu sistem peradilan".

Mahkamah mendorong negara untuk menjamin proses hukum yang adil. Aparat negara yang sewenang-wenang adalah kebalikan dari pada due process of law. Makna dari due process of law tidak hanya pada penerapan perundangundangan yang adil tetapi juga mengandung jaminan hak atas kemerdekaan dari seorang warga negara. ${ }^{14}$

Mahkamah juga memberikan petunjuk khusus terhadap perkara Nomor 6/ PUU-VIII/2010. Berikut pertimbangan Mahkamah:

"Menimbang bahwa adapun seperti penyitaan buku berjudul "Enam Jalan Menuju Tuhan" kerangan Darmawan (Pemohon perkara Nomor 6/PUUVIII/2010), menurut Mahkamah merupakan kasus konkret yang berdasarkan due process of law, penegak hukum harus menindaklanjutinya melalui instrumen hukum yang sudah tersedia seperti Undang-undang Pencegahan Penodaan Agama dan/atau KUHP”.

${ }^{13}$ Ahmad Rifai, Penemuan Hukum Oleh Hakim dalam Persfektif Hukum Progresif (Sinar Grafika 2011).[90].

${ }^{14}$ Mahrus Ali, Loc. Cit. 
Dalam keadaan seperti tersebut diatas, Mahkamah tetap menilai bahwa proses secara hukum harus dilakukan karena Indonesia adalah negara hukum. Penegak hukum juga memiliki tanggung jawab untuk menjamin bahwa yang proses yang dilakukan telah sesuai dengan pengaturan hukum yang ada.

Mahkamah menilai bahwa tidak sejalan dengan konstitusi apabila sumber informasi yang menjadi hak setiap orang dilarang. Pertimbangan hukum Mahkamah telah mendukung terwujudnya perlindungan hak atas informasi. Seseorang atau kelompok yang bermaksud untuk menyebarkan informasi melalui buku tidak lagi merasa terancam karena telah dijamin dalam UUD 1945. Berikut isi pertimbangan Mahkamah:

"Pelarangan pengedaran buku-buku sebagai suatu sumber informasi, penyitaan tanpa proses pengadilan, merupakan suatu tindakan yang tidak sejalan bahkan bertentangan dengan Pasal 28F UUD 1945 yang menyatakan, "Setiap orang berhak untuk berkomunikasi dan memperoleh informasi untuk mengembangkan pribadi dan lingkungan sosialnya, serta berhak untuk mencari, memperoleh, memiliki, menyimpan, mengolah, dan menyampaikan informasi dengan menggunakan segala jenis saluran yang tersedia", Hal itu juga tidak sejalan dengan ketentuan Pasal 28E ayat (2) UUD 1945 yang menjamin, "setiap orang berhak atas kebebasan meyakini kepercayaan, menyatakan pikiran dan sikap, sesuai dengan hati nuraninya".

Hak informasi menjadi pembuka jendela peradaban dan pengembangan demokrasi di dunia pendidikan Indonesia sektor strategis lainnya. Setiap orang diberi kesempatan untuk mengembangkan dirinya melalui informasi yang mereka terima. Hak masyarakat untuk pandai, cerdas, dan tidak ketinggalan zaman, akan terganjal apabila hak untuk mendapatkan dan mendistribusikan informasi mengalami hambatan. ${ }^{15}$ Dalam perkembangannya jaminan mendapatkan informasi dan distribusinya tidak hanya pada media cetak tetapi juga media elektronik dan pemanfaatan internet termasuk di dalamnya adalah buku-buku elektronik.

Selanjutnya Mahkamah kembali menegaskan bahwa terdapat pembatasan yang diatur dalam UUD 1945, sebagaimana pertimbangan Mahkamah dibawah ini:

${ }^{15}$ Abdul Wahid, Siti Marwiyah, 'Hak Kemerdekaan Menulis Buku Menuju Pencerahan Edukasi Masyarakat' (2011) 8 Jurnal Konstitusi.[625] 
"Menimbang bahwa meskipun menurut ketentuan Pasal 28J ayat (2) UUD 1945 kebebasan seseorang dapat dibatasi dengan Undang-Undang akan tetapi pembatasan tersebut hanya untuk tujuan yang secara tegas disebutkan yakni semata-mata untuk pengakuan serta penghormatan atas hak dan kebebasan orang lain dan untuk memenuhi tuntutan yang adil sesuai dengan pertimbangan moral, nilai-nilai agama, keamanan dan ketertiban dalam suatu masyarakat demokratis. Pemberian kewenangan untuk melakukan pelarangan atas suatu yang merupakan pembatasan hak asasi tanpa melalui due process of law, jelas tidak termasuk dalam pengertian pembatasan kebebasan seperti yang dimaksud Pasal 28J ayat (2) UUD 1945”.

Demikian konstitusi Indonesia telah mengatur sedemikian rupa terkait dengan pembatasan hak asasi warga negara. Pembatasan demikian diperlukan untuk menjaga keseimbangan antara hak dan kewajiban setiap warga negara sehingga ketertiban akan terwujud.

Seperti dalam memproses penyitaan terhadap suatu barang, Mahkamah juga memberikan contoh kasus apabila memang diperlukan untuk menyita barang terlebih dahulu. Dalam hal ini proses hukum harus tetap dilakukan sesuai dengan aturan yang ada, berikut pernyataan Mahkamah:

"Dalam kejadian seperti itu, misalnya seperti penyitaan buku berjudul, "Enam Jalan Menuju Tuhan sebagaimana disebutkan diatas, aparatur negara yang berwenang dapat saja melakukan penyitaan setelah mendapatkan izin dari ketua Pengadilan Negeri setempat atau menyita terlebih dahulu dalam hal mendesak, lalu meminta izin persetujuan penyitaan dari ketua pengadilan negeri setempat dilanjutkan dengan penyidikan, penuntutan dan penyidangan oleh instansi yang berwenang menurut Undang-Undang yang berlaku. Semua penegakan hukum pada akhirnya ditentukan dalam putusan pengadilan yang telah memperoleh kekuatan hukum tetap. Hanya dalam putusan pengadilan dapat ditentukan apakah suatu barang yang semula telah disita ditetapkan untuk dirusakkan, atau dimusnahkan, atau dirampas untuk negara atau dikembalikan kepada orang yang dari padanya sebuah barang disita. Tak hanya bisa melarang, menyita, menahan, memenjarakan bahkan menjatuhkan pidana mati sekalipun diperbolehkan asal melalui proses peradilan, bukan melalui keputusan Jaksa Agung”.

Pada akhir pertimbangan hukumnya Mahkamah mengambil kesimpulan mengabulkan permohonan Para Pemohon yaitu Pasal 1 sampai dengan 9 UU 4/ PNPS/1963. Dengan demikian UU 4/PNPS/1963 dinyatakan bertentangan dengan UUD 1945 sehingga tidak mempunyai kekuatan hukum mengikat. 
Selanjutnya mengenai pengujian materiil Undang-Undang Nomor 16 Tahun 2004 tentang Kejaksaan RI, Mahkamah memberikan pertimbangan hukum sebagai berikut:

"Menimbang bahwa sebagai suatu negara kesejahteraan, aparat Pemerintah seperti kejaksaan tentu diperkenankan melakukan pengawasan atas barang cetakan apakah barang cetakan tersebut isinya tidak bertentangan atau melanggar suatu Undang-Undang. Kalau dalam rangka pengawasannya tersebut terdapat barang cetakan yang isinya misalkan bertentangan atau melanggar ketentuan Undang-Undang Pornografi, tentulah kejaksaan akan menyampaikan kepada instansi yang berwenang melakukan penyidikan untuk menyidik pencetak, pemilik, pengedar barang cetakan, seterusnya penyidik dapat melakukan penyitaan, penggeledahan, bahkan mungkin penahanan tersangka, kemudian melakukan penuntutan dan penyidangan di pengadilan sesuai dengan ketentuan hukum acara pidana yang berlaku".

Menurut Mahkamah, masyarakat dapat berperan dalam pengawasan terhadap barang-barang cetakan khususnya buku yang isinya melanggar peraturan perundangundangan.

"Menimbang bahwa pengawasan barang cetakan dalam arti melakukan penyelidikan atas isi barang cetakan jikalau ada yang melanggar ketentuan hukum pidana, tidak hanya kejaksaan tetapi juga Kepolisian dan penegak hukum lainnya sesuai dengan kewenangannya masing-masing dapat melakukannya. Masyarakat juga dapat melakukan pengawasan dengan memberikan laporan kepada yang berwajib apabila suatu barang cetakan isinya melanggar Undang-Undang. Adapun ditindaklanjuti atau tidaknya suatu laporan dari masyarakat tentu tergantung dari penyelidikan yang dilakukan oleh instansi yang berwajib. Artinya kalau setelah diselidiki terbukti pelanggarannya akan dilakukan penyidikan dan proses selanjutnya. Apabila tidak cukup buktinya tentunya tidak disidik".

Selain itu Mahkamah juga menelusuri Undang-Undang Kejaksaan terdahulu yang mengatur bahwa salah satu kewenangan Kejaksaan adalah mengamankan barang cetakan. Dengan demikian Mahkamah telah melakukan analisis yang mendalam mengenai keterkaitan UU/PNPS/1963 dengan UU Kejaksaan terdahulu yang sudah tidak sesuai dengan UU Kejaksaan yang berlaku sekarang. Berikut pertimbangan Mahkamah:

"Menimbang bahwa frasa "pengawasan peredaran barang cetakan", khususnya kata "Pengawasan" menurut Mahkamah memang tidak dimaknai sebagai "Pengamanan" sebagaimana yang tersebut dalam Pasal 27 ayat (1) Undang-Undang Nomor 5 Tahun 1991 yang telah dicabut, apalagi sebagai 
"Pelarangan" sebagaimana yang tertera dalam Pasal 1 ayat (1) UndangUndang Nomor 4/PNPS/1963 yang telah dinyatakan bertentangan dengan UUD 1945. Pengawasan dapat merupakan penyelidikan, penyidikan, penyitaan, penggeledahan, penuntutan, dan penyidangan oleh instansi yang berwenang masing-masing sesuai dengan due process of law, yang berujung pada putusan pengadilan yang telah memperoleh kekuatan hukum tetap yang kemudian dieksekusi oleh kejaksaan".

Pertimbangan hukum Mahkamah tersebut bukanlah sebagai pertimbangan hukum yang mengarah pada putusan konstitusional bersyarat karena memang maksud dan tujuan pengaturan tersebut berbeda dengan pengaturan terdahulu, Mahkamah hanya memperjelas maksud dan bagaimana pengaturan tersebut dilaksanakan. Pada kesimpulannya Mahkamah menilai bahwa Undang-Undang Nomor 16 Tahun 2004 tentang Kejaksaan Republik Indonesia sesuai dengan permohonan para Pemohon sejauh menyangkut Pasal 30 ayat (3) huruf c dinyatakan konstitusional, maka permohonan para Pemohon ditolak.

\section{Amar Putusan dan Dissenting Opinion}

Pasal 45 Undang-Undang Mahkamah Konstitusi mengatur bahwa sebelum mengambil keputusan terhadap suatu perkara Hakim Konstitusi melakukan musyawarah dalam sidang pleno yang dipimpin oleh ketua sidang. Musyawarah ini dilakukan untuk mencapai mufakat antar Hakim Konstitusi. Dalam sidang permusyawaratan Hakim tersebut setiap Hakim Konstitusi wajib menyampaikan pertimbangan atau pendapat tertulis terhadap permohonan. Dalam hal musyawarah sidang pleno setelah diusahakan dengan sungguh-sungguh tidak mencapai mufakat, putusan diambil dengan suara terbanyak. Pendapat anggota Majelis hakim yang berbeda harus dimuat dalam putusan. Hakim yang mengajukan membacakan pendapatnya atau alasannya sendiri setelah ketua sidang membacakan amar putusan. ${ }^{16}$

Terkait pendapat berbeda di dalam putusan dapat dibedakan menjadi dua jenis, yaitu dissenting opinion dan concurrent opinion atau consenting opinion.

${ }_{16}$ Tim Penyusun, Hukum Acara Mahkamah Konstitusi, (Sekretariat Jendral dan Kepaniteraan Mahkamah Konstitusi 2010).[50]. 
Dissenting Opinion adalah pendapat berbeda dari anggota Majelis Hakim dari sisi substansi yang memengaruhi perbedaan amar putusan. Dissenting Opinion adalah salah satu bentuk pertanggungjawaban moral hakim konstitusi yang berbeda pendapat serta wujud transparansi agar masyarakat mengetahui seluruh pertimbangan dalam putusan Mahkamah Konstitusi. Sedangkan Concurent Opinion adalah pendapat berbeda yang tidak memengaruhi putusan. Karena isi Concurent Opinion adalah pertimbangan yang berbeda maka tidak selalu ditempatkan secara terpisah dari suara hakim mayoritas, tetapi dapat dijadikan satu untuk memperkuat amar putusan. ${ }^{17}$

Mahkamah Konstitusi memutus perkara berdasarkan UUD NRI 1945 sesuai alat bukti dan keyakinan hakim. Dalam hal putusan tersebut mengabulkan permohonan maka harus didasarkan pada sekurang-kurangnya dua alat bukti. Putusan tersebut juga wajib memuat fakta yang terungkap dalam persidangan dan pertimbangan hukum yang menjadi dasar putusan. Putusan Mahkamah Konstitusi ditandatangani oleh hakim yang memeriksa, mengadili, dan memutus, dan oleh panitera. Putusan tersebut memperoleh kekuatan hukum tetap sejak selesai diucapkan dalam sidang pleno terbuka untuk umum. Mahkamah Konstitusi wajib mengirimkan salinan putusan kepada para pihak dalam jangka waktu paling lambat tujuh hari kerja sejak putusan diucapkan. ${ }^{18}$

Terdapat tiga jenis amar putusan yang diatur di dalam pasal 56 UU Mahkamah Konstitusi yaitu permohonan tidak dapat diterima, permohonan dikabulkan, dan permohonan ditolak. Selain itu juga terdapat pula kemungkinan lainnya, yaitu perkara tersebut ditarik kembali dan Mahkamah Konstitusi menyatakan bahwa dirinya tidak berwenang. Apabila terjadi demikian Ketua Mahkamah Konstitusi menerbitkan Ketetapan Penarikan kembali yang diucapkan dalam sidang terbuka untuk umum. Dalam perkembangannya, terdapat pula amar putusan lainnya dalam praktik di Mahkamah Konstitusi yaitu Kondisional Bersyarat, Tidak Konstitusional Bersyarat, Penundaan Keberlakuan Putusan, dan Perumusan Norma dalam Putusan.

\footnotetext{
17 ibid. [58].

18 Undang-Undang Nomor 24 Tahun 2003 tentang Mahkamah Konstitusi.
} 
Amar Putusan Mahkamah Konstitusi Nomor 6-13-20/PUU-VIII/2010, Mahkamah telah memutus sebagai berikut:

1. Menyatakan permohonan pengujian formil pemohon tidak dapat diterima;

2. Menyatakan Undang-Undang Nomor 4/PNPS/1963 tentang Pengamanan Barang-barang cetakan yang isinya Dapat mengganggu ketertiban umum (lembaran negara republik Indonesia Tahun 1963 Nomor 23 Tambahan lembaran negara Republik Indonesia Nomor 2533) juncto Undang-Undang Nomor 5 tahun 1969 tentang pernyataan berbagai penetapan presiden dan peraturan presiden sebagai undang-Undang (lembaran negara Republik Indonesia nomor 2900) bertentangan dengan Undang-Undang Dasar Negara Republik Indonesia Tahun 1945 dan tidak mempunyai kekuatan hukum mengikat;

3. Pengujian Pasal 30 ayat (3) huruf c Undang-Undang Nomor 16 tahun 2004 tentang Kejaksaan Republik Indonesia (Lembaran Negara Republik Indonesia Nomor 4401) ditolak;

4. Menolak permohonan para pemohon pengujian materiil untuk selain dan selebihnya;

5. Memerintahkan pemuatan putusan ini dalam Berita Negara Republik Indonesia sebagaimana mestinya.

Dalam Putusan Mahkamah Konstitusi Nomor 6-13-20/PUU-VIII/2010, salah satu Hakim Mahkamah Konstitusi yaitu Hamdan Zoelva memiliki pendapat berbeda (dissenting opinion) yang pada pokoknya sebagai berikut:

Hamdan Zoelva mengawali pendapat berbedanya dengan dua pertanyaan yaitu konstitusionalkah pelarangan peredaran barang cetakan yang dianggap mengganggu ketertiban umum? Dan konstitusionalkah kewenangan Jaksa Agung melakukan pelarangan peredaran barang cetakan yang mengganggu ketertiban umum?.

"Perampasan kemerdekaan seseorang adalah melanggar hak asasi manusia. Akan tetapi untuk kepentingan umum penahanan terhadap seseorang dibenarkan asal diperintahkan oleh undang-undang. Demikian juga pembatasan-pembatasan kebebasan individual dalam keadaan darurat dimungkinkan berdasarkan ketentuan undang-undang (Lihat UU Nomor 23 Prp Tahun 1959 tentang Keadaan Bahaya). Demikianlah halnya dengan hak dan kebebasan untuk mengeluarkan pendapat, hak untuk mencari, memperoleh, memiliki, menyimpan, mengolah dan menyampaikan segala informasi dengan menggunakan segala jenis saluran yang tersedia, serta jaminan atas hak milik pribadi dapat dibatasi untuk kepentingan keamanan dan ketertiban umum. Akan tetapi untuk menghindari penyalahgunaan wewenang dan kekuasaan oleh pemerintah, pembatasan demikian harus dengan undang-undang". 
Hamdan Zoelva menilai bahwa kewenangan Jaksa Agung bukan pada konstitusional atau tidak tetapi pada jaminan kepastian hukum. Berikut pernyataan Hakim Hamdan Zoelva:

"Persoalan konstitusional dalam undang-undang a quo, bukanlah pada pemberian wewenang kepada Jaksa Agung melakukan pelarangan beredarnya barang cetakan, tetapi justru terletak pada tidak adanya jaminan kepastian hukum, tindakan Jaksa Agung tersebut apakah dilakukan berdasarkan prinsip due process of law, sehingga potensial melanggar prinsip negara hukum dan prinsip pengakuan, jaminan, perlindungan serta kepastian hukum yang adil bagi warga negara. Tidak adanya jaminan ini, mengakibatkan ketentuan tersebut menjadi bertentangan dengan konstitusi. Dengan demikian diperlukan persyaratan tertentu agar tindakan Jaksa Agung memenuhi prinsip due process of law, yaitu keputusan melarang peredaran barang cetakan harus terlebih dahulu mendapat izin dari pengadilan, sehingga siapapun yang merasa dirugikan dapat melakukan perlawanan (verzet) melalui pengadilan. Dengan tambahan syarat ini terpenuhilah prinsip due process of law dan kepastian hukum yang adil atas tindakan Jaksa Agung".

Pada kesimpulannya Hakim Hamdan Zoelva berpendapat bahwa putusannya seharusnya inkonstitusional bersyarat. Jika didasarkan pada amar putusan yang diatur dalam UU Mahkamah Konstitusi maka sulit untuk menguji UU di mana sebuah UU seringkali mempunyai sifat yang dirumuskan secara umum, padahal dalam rumusan yang sangat umum itu belum diketahui dilaksanakan sesuai UUD atau tidak. ${ }^{19}$ Maka demikian Hakim Hamdan Zoelva mengajukan beberapa syarat, berikut pendapatnya:

Berdasarkan pertimbangan tersebut di atas saya berpendapat bahwa Pasal 1 ayat (1) UU Nomor 4/PNPS/1963 adalah inkonstitusional bersyarat (conditionally unconstitusional), yaitu bertentangan dengan UUD 1945, sepanjang tidak dimaknai:

1. Wewenang Jaksa Agung untuk melarang peredaran barang cetakan hanya dapat dilakukan setelah terlebih dahulu mendapat izin dari pengadilan.

2. Alasan melanggar ketertiban umum paling tidak harus memenuhi tiga unsur, yaitu:

a. Perbuatan mengedarkan barang cetakan tersebut adalah perbuatan yang melanggar ketentuan undang-undang;

b. Akibat peredaran barang cetakan tersebut menimbulkan terganggunya ketertiban umum.

${ }^{19}$ Tim Penyusun, Op.Cit.[144]. 
c. Terganggunya ketertiban umum tersebut harus nyata atau potensial pasti terjadi.

Sepanjang kedua persyaratan konstitusional tersebut dipenuhi, tidak ada norma dalam seluruh pasal UU Nomor 4/PNPS/1963 yang bertentangan dengan UUD 1945.Terhadap permohonan para Pemohon mengenai Pasal 30 ayat (3) huruf c, Undang-Undang Nomor 16 Tahun 2004 tentang Kejaksaan, saya memiliki pertimbangan dan pendapat yang sama bahwa Pasal 30 ayat (3) huruf $\mathrm{c}$ tersebut tidak bertentangan dengan UUD 1945 sehingga permohonan para pemohon ditolak.

Putusan Mahkamah Konstitusi Nomor 6-13-20/PUU-VIII/2010 menyatakan bahwa pelarangan pengedaran buku tanpa proses di pengadilan adalah tindakan yang tidak sejalan dan bertentangan dengan UUD NRI 1945. Pelarangan yang didasarkan pada pemberian kewenangan adalah pembatasan hak asasi manusia yang tidak sesuai dengan Pasal 28J ayat (2) UUD NRI 1945. Dalam pertimbangan hukumnya Mahkamah Konstitusi memberikan petunjuk bahwa Kejaksaan dapat melaksanakan upaya penyitaan setelah ada izin dari pengadilan. Kejaksaan dapat juga dapat mengawasi peredaran barang cetakan melalui upaya penyelidikan, penyidikan, penyitaan, penggeledahan, penuntutan, dan penyidangan sesuai dengan due process of law. Putusan Mahkamah yang telah mengabulkan dan diumumkan dalam berita negara menjadi perubahan hukum yang harus ditaati oleh semua orang termasuk penegak hukum.

\section{Hak Asasi Manusia}

Hak Asasi Manusia adalah hak dasar yang melekat pada manusia sejak lahir sebagai karunia Tuhan Yang Maha Esa. Pada setiap manusia yang lahir melekat hak-hak dasar yang menyertai kelahiran manusia secara alamiah. Hak asasi manusia merupakan suatu hasil temuan yang bernilai universal dalam sejarah peradaban manusia. Oleh sebab itu, hak asasi manusia difungsikan dalam kehidupan antar manusia yang menyeluruh pada tataran global. Secara universal pula hak asasi manusia menjadi pedoman dalam membangun dunia yang lebih damai dan bebas 
dari ketakutan dan penindasan serta perlakuan yang tidak adil. ${ }^{20}$

Pada tahun 1948 setelah perang dunia ke II berakhir, negara-negara di dunia berkumpul melalui Perserikatan Bangsa-Bangsa dan menyepakati suatu Universal Declaration of Human Right (Deklarasi Universal Hak Asasi Manusia atau DUHAM). Deklarasi ini ditetapkan oleh badan khusus Perserikatan BangsaBangsa yaitu ECOSOC (Economic and social council-Dewan Sosial Ekonomi) pada tanggal 10 Desember 1948. Karena berbentuk deklarasi DUHAM tidak memiliki kekuatan mengikat secara hukum. Negara anggota PBB diharapkan dapat mencantumkan dalam Undang-Undang Dasar Negara masing-masih atau peraturan turunannya. Dalam paham negara hukum selanjutnya jaminan perlindungan hak asasi manusia dianggap ciri yang mutlak yang harus ada di setiap negara yang disebut rechtsstaat. ${ }^{21}$

Setelah 18 tahun kemudian yakni pada tahun 1966 PBB berhasil melahirkan sebuah konvensi internasional. Dalam perkembangannya setelah mengukuhkan DUHAM ternyata tidak cukup untuk mengurangi akar-akar penindasan di negaranegara anggota PBB. Hasil dari konvensi internasional itu adalah Covenant on Economic, Social, and Culture Right (Kovenan tentang Hak-Hak Ekonomi, Sosial, dan Budaya) serta Covenant Civil and Political Rights (Kovenan tentang Hak-Hak Sipil dan Politik). Kedua kovenan tersebut dapat dirumuskan sebagai peraturan pelaksanaan naskah pokok DUHAM. Selain itu keduanya juga dapat disebut sebagai sumbangan terhadap perjuangan hak-hak asasi manusia. Meratifikasi kedua covenant ini menyebabkan negara-negara terikat secara hukum. ${ }^{22}$

Hak asasi manusia sebagai nilai universal telah termuat di dalam Konstitusi Indonesia. Pada pembukaan dan batang tubuh UUD NRI 1945 telah memuat jaminan terhadap hak asasi manusia yaitu dalam Pasal 28. Sebagai bentuk tanggung jawab moral dan hukum sebagai anggota PBB, Indonesia juga memiliki UndangUndang Nomor 39 Tahun 1999 tentang Hak Asasi Manusia. Undang-undang ini

\footnotetext{
${ }^{20}$ Jimly Assiddiqie, Pengantar Ilmu Hukum Tata Negara (PT. Raja Grafindo Persada 2013).[343].

${ }^{21}$ ibid.

22 ibid.[349].
} 
adalah bentuk penghormatan dan pelaksanaan DUHAM tahun 1948. Pada tahun 2005 Indonesia telah meratifikasi dua kovenan internasional yakni melalui UndangUndang Nomor 11 Tahun 2005 Tentang Pengesahan International Covenant on Economic, Social, and Cultural Rights (ICESCR) dan Undang-Undang Nomor 12 Tahun 2005 Tentang Pengesahan International Covenant on Civil and Political Rights (ICCPR). Sejak saat itu Indonesia terikat secara hukum terhadap ketentuan kedua kovenan tersebut.

Kebebasan dasar dan hak-hak itulah yang disebut sebagai hak asasi manusia yang melekat pada manusia secara kodrati sebagai anugerah Tuhan Yang Maha Esa. Hak-Hak ini tidak dapat diingkari, pengingkaran terhadap hak tersebut berarti mengingkari martabat kemanusiaan. Oleh karena itu, negara, pemerintah, atau organisasi apapun mengemban kewajiban untuk melindungi hak asasi manusia pada setia manusia tanpa terkecuali. Ini berarti bahwa hak asasi manusia harus selalu menjadi titik tolak dan tujuan dalam penyelenggaraan kehidupan bermasyarakat, berbangsa, dan bernegara. ${ }^{23}$

\section{Prinsip dan Standar Hak Asasi Manusia}

Berkaitan dengan prinsip Hak Asasi Manusia terdapat delapan prinsip mendasar yang mejadi pedoman mengatur hubungan antara individu atau kelompok dengan negara. Pertama adalah kesetaraan (equality) yaitu penghargaan terhadap martabat seluruh insan manusia sebagaimana yang dinyatakan dalam pasal 1 DUHAM bahwa semua insan manusia dilahirkan bebas dan setara dalam martabat dan hak-haknya. Kedua, non-diskriminasi yaitu tidak seorang-pun diingkari hak asasinya karena alasan-alasan seperti ras, warna kulit, agama, seks, bahasa, atau asal nasional. Ketiga, universalitas yaitu nilai moral dan etika tertentu dimiliki bersama di seluruh wilayah dunia, tidak terbatas wilayah negara. Keempat yakni martabat Manusia adalah prinsip dimana hak asasi harus didasarkan pada pandangan bahwa setiap individu, patut untuk dihargai dan dijunjung tinggi.

\footnotetext{
${ }^{23}$ Penjelasan Umum Undang-Undang Nomor 39 Tahun 1999 tentang Hak Asasi Manusia
} 
Kelima, tidak dapat direnggut (inalienability) yaitu bahwa hak yang dimiliki tidak dapat dicabut, dilepaskan, diserahkan atau dipindahkan. Keenam, tanggung jawab yaitu bahwa negara, individu dan kolompok masyarakat termasuk korporasi memiliki tanggung jawab menjaga, menghargai, dan promosi perlindungan hak asasi. Ketujuh, indivisible adalah bahwa hak-hak asasi manusia harus dilihat sebagai satu kesatuan dan tidak dapat dipisahkan dari hak lainnya seperti hak sipil, politik, sosial, ekonomi dan budaya. Terakhir yaitu interdependensi adalah bahwa hak asasi terwujud pada semua aspek kehidupan, termasuk di rumah, sekolah, tempat kerja dan ditempat lainnya. ${ }^{24}$

Merujuk kepada prinsip-prinsip hak asasi manusia tersebut pelarangan buku harus didasarkan kepada prinsip-prinsip yang memiliki hubungan dengan pelarangan buku. Walaupun sebenarnya semua prinsip tersebut berhubungan tetapi menurut penulis ada tiga prinsip yang memiliki hubungan langsung dengan pelarangan buku yaitu prinsip tanggung jawab negara, indivisible, dan interdependensi. Mengenai tanggung jawab negara, pemerintah memiliki kewajiban untuk menjaga dan menghormati hak-hak warga negaranya melalui kewenangan-kewenangan yang dimilikinya. Salah satu diantaranya adalah membentuk peraturan yang menjamin terpenuhinya hak asasi yang dimiliki warga negara kaitannya dengan pelarangan buku. Dalam hal ini pemerintah telah mengesahkan Undang-Undang Nomor 3 Tahun 2017 tentang Sistem Perbukuan dan peraturan pelaksanaannya.

Prinsip yang memiliki hubungan selanjutnya adalah prinsip indivisible. Beberapa buku memiliki substansi yang berkaitan dengan hak asasi manusia, tentu hal ini sangat mendukung kampanye mengenai hak asasi manusia. Sementara itu sebagai bagian dari kebebasan ekspresi buku memiliki peluang bagi terwujudnya jaminan atas hak-hak asasi lainnya serta juga mengungkap pelanggaran-pelanggaran terhadapnya. Berkenaan dengan hal tersebut prinsip indivisible ini adalah penting guna mendasari pelarangan suatu buku. Prinsip ketiga yaitu interdependensi memiliki kaitannya dengan pelarangan buku harus mencakup berbagai sarana dan

\footnotetext{
HAM 2017).

${ }^{24}$ Herlambang P. Wiratraman, Prinsip-prinsip Hak Asasi Manusia (Pusat Studi Hukum dan
} 
prasarana lain yang berhubungan dengan pelarangan tersebut. Dengan kemajuan mesin teknologi dan informasi, prinsip interdependensi ini menjadi salah satu yang menjadi komponen penting terhadap terwujudnya hak asasi yang tidak terbatas pada tempat dan waktu.

Menurut I Dewa Gede Atmaja, berkenaan dengan tolok ukur, Hak Asasi Manusia memiliki standar yang sangat kompleks. Standar Hak Asasi Manusia paling sedikit dapat dikonfigurasikan dalam tiga acuan, yang pertama adalah filsafat Hak asasi manusia, yang kedua teori HAM, dan terakhir konsep good governance. Sudut pandangnya dapat diuraikan sebagai berikut: ${ }^{25}$

Dari sudut pandang filsafat dapat diperbandingkan tiga konsep filsafat yakni Pancasila, Barat, dan Marxis yang diuraikan dalam tabel. ${ }^{26}$

Tabel 1. Konsep perbandingan HAM: Pancasila, Barat, dan Marxis.

\begin{tabular}{|c|c|c|c|}
\hline Uraian & Filsafat Pancasila & Filsafat Barat & Filsafat Marxis \\
\hline & Secara Instriksik & Bersumber pada & Bersumber pada \\
\hline & melekat pada Pancasila & hukum alam/hukum & ajaran Karl Marx \\
\hline & yang merupakan & kodrat, HAM adalah & \\
\hline & Grundnorm. & hak alamiah & \\
\hline \multirow[t]{3}{*}{ Hak dan Kewajiban } & Adanya hak & Mengutamakan & Mengutamakan \\
\hline & berbarengan dengan & Hak dan meletakan & kewajiban terhadap \\
\hline & kewajiban & kewajiban pada negara & negara \\
\hline \multirow[t]{2}{*}{ Standar } & Keseimbangan Hak & Individu otonom dan & Kepentingan \\
\hline & dan Kewajiban & kebebasan & Negara \\
\hline
\end{tabular}

Hak-hak dan kewajiban asasi manusia di Indonesia sangat erat kaitannya dengan sila kedua yaitu kemanusiaan yang adil dan beradab. Pancasila dan UUD NRI 1945 merupakan sumber hukum dasar nasional. Dalam Pancasila termuat cita hukum, nilai-nilai dan pandangan hidup yang di anut Indonesia. Pancasila merupakan dasar falsafah yang memberikan pedoman terhadap implementasi Hak Asasi Manusia. Pada tabel diatas dapat diketahui bahwa pancasila yang menjadi falsafah menekankan adanya keseimbangan dan keserasian antara hak dan kewajiban asasi manusia.

${ }^{25}$ I Dewa Gede Atmaja, Hukum Konstitusi: Problematika Konstitusi Indonesia Sesudah Perubahan UUD 1945 (Setara Pres 2010).[206].

26 ibid. 
Penjabaran secara normatif yang menghubungkan regulasi dengan perlindungan HAM menjadi penting kemudian. Secara konstitusional di Indonesia, UUD NRI 1945 Pasal 28 I ayat (5) mengatur bahwa untuk menegakkan dan melindungi hak asasi manusia sesuai dengan prinsip negara hukum yang demokratis, maka pelaksanaan hak asasi manusia dijamin, diatur, dan dituangkan dalam peraturan perundang-undangan. Hal ini menegaskan bahwa hak asasi manusia hanya dapat dilaksanakan ketika hak tersebut telah diatur dan dituangkan dalam peraturan perundang-undangan. Hak demikianlah yang memperoleh justifikasi konstitusional dan bertransformasi dari hak moral menjadi hak legal. ${ }^{27}$ Mengenai hak moral dan hak legal terdapat hal yang membedakan. Hak moral didasarkan atas prinsip atau peraturan etis saja, sedangkan hak legal adalah hak-hak yang berasal dari undang-undang, peraturan hukum atau dokumen legal lainya.

Standar hukum HAM kedua adalah dari sudut pandang teoritis yakni mencakup: $:^{28}$

1. Naturalist; inti dari pandangannya bahwa HAM adalah hak setiap manusia yang besifat abadi dan universal berdasarkan takdirnya sebagai manusia. HAM sebagai hak kodrati. Dipengaruhi oleh pandangan John Locke, bahwa standar HAM adalah perlindungan atas manusia sebagai pribadi otonom dan kebebasan individu. HAM merupakan pilihan sosial dari visi moral tertentu dari potensi manusia sebagai persyaratan minimum kehidupan bermartabat.

2. Positivist; inti pandangannya bahwa HAM adalah hak karena diatur dalam hukum positif atau dijamin dalam Undang-undang. Dalam pandangan teori positivist standar HAM ditentukan oleh Undang-Undang sebagai produk politik.

3. Utilitarianism; memandang HAM adalah sarana pemenuhan kepentingan bersama untuk memenuhi kebahagiaan sebesar-besarnya bagi sebanyakbanyaknya orang.

4. Realist; pendekatan Marxian terhadap HAM, pada intinya menolak teori hukum alam/kodrati yang menganut paham metafisik. Sumber HAM adalah negara dan kolektivitas masyarakat. Individu telah diceraikan dari masyarakat, hakhak diperlukan negara kapitalis dalam rangka menyediakan perlindungan dari negara. Marx mengecam hak sebagai rekayasa masyarakat borjuis.

\footnotetext{
${ }^{27}$ Harison Citrawan, 'Analisis Dampak Hak Asasi Manusia Atas Regulasi: Sebuah Tinjauan Metodologi' (2017) 8 Jurnal HAM.[17].

${ }_{28}$ Herlambang P. Wirtraman, 'Teori-Teori Hak Asasi Manusia (Human Rights Theories)' (Handout Kuliah Fakultas Hukum Universitas Airlangga) 3 September 2019.
} 
Yang ketiga adalah standar HAM menurut pandangan good governance yang menentukan tiga standar HAM yaitu a) Pemerintahan yang tidak sewenang-wenang; b) Pelayanan Pemerintah yang tidak diskriminatif; dan c) regulasi yang memihak kepada rakyat. Terkait dengan pandangan good governance banyak perbedaan menurut para ahli, dimana bila diperbandingkan dari beberapa pendekatan maka pendekatan hak asasi manusia yang dapat dipakai. Berbeda dengan good governance pada umumnya yang berfokus pada pembangunan manusia dan sifat yang hanya administratif saja. Tujuan dari pendekatan hak asasi manusia adalah perwujudan seluruh hak-hak asasi manusia dengan fokus pada perlindungan dan penikmatan hak asasi manusia oleh semua orang dan komunitas khususnya orang miskin dan rentan. Dalam hal ini good governance memiliki elemen-elemen inti yaitu aturan yang berkeadilan, kesederajatan, perlindungan dan penikmatan hak-hak untuk semua, perencanaan rakyat dan implementasi. ${ }^{29}$

\section{Pembatasan Kebebasan Ekspresi}

Pembatasan HAM di dalam sebuah sistem hukum merupakan sarana pencapaian hukum pada umumnya. Pembatasan HAM dalam hukum Internasional secara terminologi identik dengan human rights limitations atau exception bukan derogation atau pengurangan. Pembatasan ini diperbolehkan sepanjang memenuhi syarat-syarat umum pembatasan HAM, yakni hukum (law), Kebutuhan (necessity), dan masyarakat yang demokratis (democratic society) dan syarat-syarat yang lebih spesifik seperti keamanan nasional (national security), keselamatan umum (public safety or order), kesehatan (health) moral, serta hak dan kebebasan orang lain.30

Terkait dengan perbukuan pembatasan kebebasan berekspresi menunjukkan keseimbangan konsep keseimbangan antara kewajiban dan tanggung jawab khusus dalam sistem HAM. Pasal 28J ayat (2) UUD NRI 1945 memuat ketentuan mengenai

${ }^{29}$ Herlambang P. Wiratraman, 'Neo-Liberalisme, Good Governance dan Hak Asasi Manusia’ (2007) 25 Jurnal Hukum Jentera.[8].

30 Al Khanif, Hak Asasi Manusia: Dialektika Universalisme vs Relativisme di Indonesia (LKiS 2017).[270]. 
dimungkinkannya pembatasan hak dan kebebasan seseorang dengan UndangUndang, tetapi pembatasan terhadap hak-hak tersebut harus didasarkan pada alasan-alasan yang kuat, masuk akal dan proporsional serta tidak boleh berlebihan.

ICCPR mengklasifikasikan bahwa the freedom of expression sebagai derogable rights sehingga pelaksanaannya dapat dibatasi sesuai dengan ketentuanketentuan yang diatur didalami ICCPR. Pembatasan the freedom expression diatur dalam artikel 19 paragraf 3 ICCPR menyatakan:

The exercise of the rights provided for in paragraph 2 of this article carries with it special duties and responsibilities. It may therefore be subject to certain restriction, but these shall only be such as are provided by law and are necessary:

a. For respect of the rights or reputation of others;

b. For the protection of nationality security or of public order (order public), or of public health or morals.

Paragraf tersebut menunjukkan bahwa pelaksanaan hak-hak yang dicantumkan pada pada paragraph 2 pasal ini menimbulkan kewajiban dan tanggung jawab khusus. Oleh karenanya dapat dikenakan pembatasan tertentu, tetapi hal ini hanya dapat dilakukan sesuai dengan hukum dan sepanjang diperlukan untuk menghormati hak dan reputasi individu lainnya dan melindungi keamanan nasional atau ketertiban umum, serta melindungi kesehatan moral publik. Tentu pembatasan atau pelarangan buku yang didasarkan pada alasan-alasan tersebut dapat diterima.

Selain itu Undang-Undang Nomor 39 Tahun 1999 Tentang Hak Asasi Manusia juga mengatur mengenai pembatasan khususnya kebebasan berekspresi yakni dalam Pasal 23 Ayat (2) Setiap orang bebas untuk mempunyai, mengeluarkan dan menyebarluaskan pendapat sesuai hati nuraninya, secara lisan dan atau tulisan, melalui media cetak atau elektronik dengan memperhatikan nilai-nilai agama, kesusilaan, ketertiban, kepentingan umum, dan keutuhan bangsa. Memang pembatasan yang diatur dalam Undang-Undang tersebut masih bersifat umum, tetapi hal tersebut dapat digunakan dengan jelas dan proporsional untuk menjamin perlindungan hak asasi manusia khususnya kebebasan ekspresi.

Selain pembatasan yang diatur dalam UUD NRI 1945 dan ICCPR serta UndangUndang Hak Asasi Manusia pembatasan lebih detail juga dirumuskan dalam sebuah 
prinsip yang dipakai untuk membatasi hak asasi manusia khususnya yang diatur dalam ICCPR. Rumusan pembatasan tersebut dikenal dengan The Siracusa Principles on Limitation and Derogation Provisions in International Covenant on Civil and Political Rights. Rumusan tersebut dibuat pada tahun 1985 dimana pada waktu itu para ahli hukum internasional Amerika Serikat yang tergabung dalam International Commissions of Jurists melihat bahwa pernyataan negara sedang dalam keadaan bahaya atau darurat sering digunakan pemerintah Amerika Serikat untuk menekan hak-hak rakyat kebebasan berkespresi termasuk hak kebebasan berpendapat. ${ }^{31}$

Prinsip Sicacusa menyebutkan bahwa pembatasan hak tidak boleh membahayakan esensi hak. Pembatasan harus ditafsirkan secara tegas dan ditujukan untuk mendukung hak dan tidak boleh dilakukan secara sewenang-wenang tanpa alasan yang sah. Berikut pembatasan yang disebutkan dalam Prinsip Siracusa:

i. Prescribed by law (diatur oleh hukum);

ii. In a democratic society (di dalam masyarakat yang demokratis);

iii. Public order (dalam rangka menjaga ketertiban umum);

iv. Public health (melindungi kesehatan masyarakat);

v. Public morals (untuk melindungi moral masyarakat);

vi. National security (untuk melindungi keamanan nasional);

vii. Public safety (untuk melindungi keselamatan publik);

viii. Rights and freedoms of others or rights and reputations of others (melindungi hak dan kebebasan orang lain).

Khusus terkait dengan keamanan negara terdapat pula rumusan Prinsip Johannesburg yang isinya mengenai pembatasan kebebasan ekspresi. Mengenai isu keamanan dan ketertiban yang sering digunakan sebagai alasan pelarangan buku pengaturan dalam Prinsip Johannesburg menegaskan kembali pasal-pasal ICCPR bahwa hak berpendapat, hak kebebasan ekspresi, dan hak untuk menyampaikan atau memperoleh informasi melekat pada setiap orang. Di dalamnya juga mengatur mengenai pembatasan yang hanya diperkenankan dengan alasan-alasan yang diatur dalam hukum internasional. Salah satu alasan yang dapat digunakan adalah dalam rangka melindungi keamanan nasional yang sah.

${ }^{31}$ Herlambang P. Wiratraman et al., Kebebasan Berekspresi di Indonesia: Hukum, Dinamika, Masalah, dan Tantangannya (Lembaga Studi dan Advokasi Masyarakat (ELSAM) 2016).[35]. 
Prinsip Johannesburg tidak menjelaskan secara gamblang mengenai yang dimaksud dengan melindungi keamanan yang sah, tidak jelas ukuran atau indikator dari kepentingan keamanan nasional yang sah itu. Tetapi pada rumusannya terdapat aturan yang memuat syarat yang harus dipenuhi ketika pemerintah suatu negara sebelum melaksanakan pembatasan hak kebebasan ekspresi yaitu pemerintah harus dapat menunjukkan bukti bahwa ekspresi dan atau informasi yang dibatasi itu mengancam keamanan nasional yang sah. Pembatasan yang dilakukan oleh pemerintah yang juga harus serendah mungkin tingkatannya dan tidak boleh bertentangan dengan prinsip-prinsip demokrasi. Masih menurut prinsip ini, pembatasan dengan alasan keamanan nasional, dianggap tidak sah apabila tujuan dan dampaknya dalam rangka untuk melindungi keberadaan suatu negara atau integritas teritorialnya dari penggunaan atau ancaman kekerasan dari luar maupun dari dalam negara tersebut. ${ }^{32}$

Pembatasan kebebasan ekspresi juga tidak dapat dilakukan untuk menutupnutupi informasi tentang kinerja institusi negara, termasuk menutup-nutupi kesalahan negara atau melindungi dari rasa malu negara akibat terungkapnya kesalahan negara. Di Indonesia misalnya, sebelum adanya putusan Mahkamah Konstitusi Nomor 6-13-20/PUU-VIII/2010 dan Undang-undang Sistem Perbukuan di tahun 2008 Jaksa Agung melarang buku berjudul Pemusnahan Etnis Melanesia Memecah Kebisuan Sejarah Kekerasan di Papua Barat karya Socratez Sofyan Yoman. Tentu kejadian seperti itu tidak boleh terulang kembali karena pada saat itu memang belum ada instrumen hukum yang lebih menjamin mengenai kebebasan ekspresi dan penegasan pembatasannya. Saat ini instrumen hukum itu sudah ada dan pemerintah wajib untuk mentaati dan menjamin pelaksanaannya.

\section{Pengaturan Pelarangan Buku Kaitannya Dengan Hak Asasi Manusia}

Undang-Undang Nomor 3 tahun 2017 Tentang Sistem Perbukuan mengatur mengenai pengawasan terhadap perbukuan khususnya diatur dalam bab IX.

32 ibid.[71]. 
Pemerintah pusat, Pemerintah daerah, pelaku perbukuan, dan masyarakat melakukan pengawasan atas sistem perbukuan agar sistem perbukuan terselenggara dengan baik. Pasal 69 ayat (3) mengatur bahwa Kejaksaan Republik Indonesia turut melakukan pengawasan terhadap substansi Buku untuk mewujudkan ketertiban dan ketenteraman umum. Dalam penjelasan pasal lebih lanjut menjelaskan bahwa pengawasan yang dilakukan Kejaksaan Republik Indonesia dimaksudkan sebagai pencegahan terjadinya tindak pidana dalam rangka mendukung penegakan hukum, baik preventif maupun edukatif di bidang ideologi, politik, sosial budaya, pertahanan, dan keamanan sehingga tercipta ketertiban dan ketentraman umum.

Pengaturan lebih lanjut mengenai pengawasan dalam Sistem Perbukuan diatur dalam Peraturan Pemerintah Nomor 75 Tahun 2019 tentang Peraturan Pelaksanaan UU Nomor 3 Tahun 2017 tentang Sistem Perbukuan. Pasal 61 kembali menegaskan bahwa Kejaksaan Republik Indonesia turut melakukan pengawasan terhadap substansi buku untuk mewujudkan ketertiban dan ketenteraman umum. Pengawasan dilaksanakan sesuai tugas dan fungsinya yakni juga berkoordinasi dengan lembaga yang menyelenggarakan urusan di bidang perbukuan. Lebih jelas lagi Pasal 62 mengatur bahwa dalam hal buku: a. tidak memenuhi syarat isi Buku; dan/atau b. mengganggu ketertiban dan ketentraman umum, Kejaksaan Republik Indonesia dapat menarik sementara Buku dari peredaran untuk buku cetak dan memblokir sementara untuk Buku elektronik paling lama 60 (enam puluh) hari kerja.

Pengaturan pengawasan dalam Undang-undang Sistem Perbukuan dan Peraturan Pelaksananya telah sesuai dengan Kewenangan Kejaksaan dalam Undang-undang Nomor 16 tahun 2004 tentang Kejaksaan dan Putusan Mahkamah Konstitusi nomor 6-13-20/PUU-VIII/2010. Secara eksplisit Pasal 30 ayat (3) Undang-Undang Kejaksaan menyatakan bahwa dalam bidang ketertiban dan ketenteraman umum, kejaksaan turut menyelenggarakan kegiatan: c) pengawasan peredaran barang cetakan. Yang dimaksud dengan turut menyelenggarakan adalah mencakup kegiatan-kegiatan bersifat membantu, turut serta, dan bekerja sama. Putusan Mahkamah Konstitusi nomor 13-20/PUU-VIII/2010 juga menegaskan bahwa pasal dalam Undang-undang ini tetap konstitusional. 
Ketentuan kewenangan Kejaksaan yang dapat menarik sementara buku paling lama 60 hari adalah selaras dengan Putusan Mahkamah Konstitusi yang memberikan penegasan bahwa Kejaksaan Agung tidak bisa langsung melarang atau mengamankan peredaran barang cetakan secara sewenang-wenang. Kewenangan Kejaksaan yang dapat menarik sementara buku tersebut tidak kemudian dijelaskan lebih lanjut bagaimana proses setelah penyitaan tersebut. Dalam kondisi seperti inilah Putusan Mahkamah Konstitusi Nomor 6-13-20/PUU-VIII/2010 memiliki implikasi hukum yaitu dengan mengharuskan Kejaksaan Agung melewati mekanisme hukum yaitu peradilan untuk menentukan barang cetakan itu melanggar hukum atau tidak.

Pengaturan pelarangan buku tersebut baik yang terdapat dalam Undangundang Sistem Perbukuan maupun Putusan Mahkamah Konstitusi adalah telah sesuai dengan standar hukum hak asasi manusia. Penegasan jaminan kebebasan ekspresi, kebebasan akademik, dan kepastian hukum terdapat dalam pertimbangan hukum mahkamah dalam putusan serta alasan dalam pembentukan pengaturan sistem perbukuan. Bahwa peristiwa-peristiwa yang terjadi seperti di bagian awal penulisan ini, tidak didasari pada peraturan-peraturan perundangan yang berlaku khususnya Undang-undang sistem perbukuan dan peraturan pelaksanaannya. Prosedur pelarangan buku yang digunakan adalah sewenang-wenang dengan kriteria yang tidak jelas dan mereka tentukan sendiri. Tindakan aparat negara tersebut dapat dikategorikan sebagai bentuk pelanggaran hak asasi manusia dan mengingkari kewajiban negara untuk menghormati (to respect), melindungi (to protect) dan memenuhi (to fulfill) hak asasi manusia.

\section{Kesimpulan}

Pelarangan buku yang terjadi tidak memberikan jaminan hukum yang pasti dan hanya didasarkan kepada keputusan pemerintah yang berkuasa secara sepihak. Putusan Mahkamah Konstitusi Nomor 6-13-20/PUU-VIII/2010 menyatakan UU 4/PNPS/1963 yang menjadi dasar hukum pelarangan buku bertentangan dengan UUD NRI 1945 dan tidak memiliki kekuatan hukum mengikat lagi. Putusan tersebut menjadi dasar bagi masyarakat perbukuan untuk berperan lebih aktif 
untuk mencerdaskan dan menyejahterakan kehidupan bangsa melalui buku-buku yang mereka terbitkan dan mereka baca. Putusan tersebut menegaskan tidak berwenang Kejaksaan Agung untuk mengamankan sebuah barang cetakan akan tetapi Kejaksaan Republik Indonesia masih tetap memiliki kewenangan untuk melakukan pengawasan terhadap barang cetakan termasuk buku berdasarkan peraturan-perundang-undangan yang berlaku. Putusan Mahkamah Konstitusi tersebut memberikan petunjuk bahwa mekanisme pelarangan buku harus melalui putusan pengadilan yang berkekuatan hukum tetap.

Pengaturan pelarangan buku di Indonesia telah sesuai dengan standar Hukum Hak Asasi Manusia. Bahwa Hak Asasi Manusia memberikan perlindungan bagi warga negara dari tindakan sewenang-wenang pemerintah yang berkuasa. Dalam perkembangannya Hak Asasi Manusia memiliki peran besar terhadap demokrasi suatu bangsa. Negara Indonesia melalui Pancasila dan UUD NRI 1945 serta berbagai Undang-undang telah menjamin bahwa Hak Asasi Manusia adalah bagian dari titik tolak penyelenggaraan negara. Buku adalah sarana bagi kebebasan berekspresi dan kebebasan akademik yang merupakan hak asasi yang dijamin dalam UndangUndang dan dalam pelaksanaannya harus ada jaminan perlakuan hukum yang adil. Hak Asasi Manusia khususnya kebebasan berekspresi memiliki batasan-batasan yang diatur dalam Pasal 28 J UUD NRI 1945 dan ICCPR pada Pasal 19 ayat (3) serta UU Nomor 39 tahun 1999 Tentang Hak Asasi Manusia. Terkait dengan Lahirnya Undang-Undang Nomor 3 Tahun 2017 Tentang Sistem Perbukuan dalam pengaturan mengenai syarat-syarat buku yang harus dipenuhi masyarakat perbukuan telah sesuai dengan standar hukum Hak Asasi Manusia yang telah diatur perundang-undangan maupun prinsip-prinsip yang diakui oleh hukum internasional.

\section{Daftar Bacaan}

\section{Buku}

Assiddiqie, Jimly, Pengantar Ilmu Hukum Tata Negara (PT. Raja Grafindo Persada 2013).

Atmaja, I Dewa Gede, Hukum Konstitusi: Problematika Konstitusi Indonesia 
Sesudah Perubahan UUD 1945 (Setara Pres 2010).

Khanif, Al, Hak Asasi Manusia: Dialektika Universalisme vs Relativisme di Indonesia (LKiS 2017).

Marzuki, P. Mahmud, Penelitian Hukum, (Kencana Prenada Media Grub 2005).

Palguna, I D G, Mahkamah Konstitusi Dalam Transisi Demokrasi, Konstitusi dan Ketatanegaraan Indonesia Kontemporer (The Biography Institute 2007).

Rifai, Ahmad, Penemuan Hukum Oleh Hakim dalam Persfektif Hukum Progresif (Sinar Grafika 2011).

Shidarta, Karakteristik Penalaran Hukum Dalam Konteks KeIndonesiaan, (CV. Utomo 2009).

Tim Penyusun, Hukum Acara Mahkamah Konstitusi, (Sekretariat Jendral dan Kepaniteraan Mahkamah Konstitusi 2010).

Wiratraman, HP. et al., Kebebasan Berekspresi di Indonesia: Hukum, Dinamika, Masalah, dan Tantangannya (Lembaga Studi dan Advokasi Masyarakat (ELSAM) 2016).

\section{Jurnal, Surat Kabar, dan Handout}

Ali, Mahrus, 'Pengawasan Peredaran Barang Cetakan, Due Process of Law dan Hak Atas Kebebasan Berpendapat' (2011) 8 Jurnal Konstitusi.

Citrawan, Harison, 'Analisis Dampak Hak Asasi Manusia Atas Regulasi: Sebuah Tinjauan Metodologi’ (2017) 8 Jurnal HAM.

Simarta, Jorawati, 'Pengujian Undang-undang Secara Formil oleh Mahkamah Konstitusi: apakah Keniscayaan? (Perbandingan Putusan Mahkamah Konstitusi Nomor 79/PUU-XII/2014 dan Putusan Mahkamah Konstitusi Nomor 27/PUU-VII/2009)' (2017) 14 Jurnal Legislasi Indonesia.

Theofany Selma, Negara di Tengah Penghancuran Literasi, (Kompas) 23 Agustus 2019.

Wahid, Abdul, Siti Marwiyah, 'Hak Kemerdekaan Menulis Buku Menuju Pencerahan Edukasi Masyarakat' (2011) 8 Jurnal Konstitusi.

Wiratraman, HP, 'Neo-Liberalisme, Good Governance dan Hak Asasi Manusia', (2007) 25 Jurnal Hukum Jentera. 
, Prinsip-prinsip Hak Asasi Manusia, (Pusat Studi Hukum dan HAM 2017).

, 'Teori-Teori Hak Asasi Manusia (Human Rights Theories)' (Handout Kuliah Fakultas Hukum Universitas Airlangga) 3 September 2019.

\section{Laman}

Hariyadi, Didit, 'Brigade Muslim Indonesia: Tak Ada Razia Buku di Gramedia', $<$ https://nasional.tempo.co/read/1232103/brigade-muslim-indonesia-takada-razia-buku-di-gramedia $>$, accesed 10 Agustus 2019.

Rofiq, M, 'Sediakan Buku Bebaru PKI, Dua Pemuda di Probolinggo diamankan', $<$ https://news.detik.com/berita-jawa-timur/d-4643537/sediakan-bukuberbau-pki-dua-pemuda-di-probolinggo-diamankan>, accesed 29 Juli 2019, dikunjungi pada tanggal 10 Agustus 2019.

\section{Perundang-undangan}

Undang-Undang Dasar Negara Republik Indonesia Tahun 1945.

Undang-Undang Nomor 4/PNPS/1963 tentang Pengamanan Terhadap BarangBarang Cetakan Yang Isinya Dapat Mengganggu Ketertiban Umum. (Lembaran Negara Republik Indonesia Tahun 1963 Nomor 23, Tambahan Lembaran Republik Indonesia Nomor 2533).

Undang-Undang Republik Indonesia Nomor 3 Tahun 2017 tentang Sistem Perbukuan. (Lembaran Negara Republik Indonesia Tahun 2017 Nomor 102, Tambahan Lembaran Negara Republik Indonesia Nomor 6053).

Undang-Undang Republik Indonesia Nomor 24 Tahun 2003 tentang Mahkamah Konstitusi. (Lembaran Negara Republik Indonesia Tahun 2003 Nomor 98, Tambahan Lembaran Negara Republik Indonesia Nomor 4316).

Undang-Undang Republik Indonesia Nomor 39 Tahun 1999 tentang Hak Asasi Manusia (Lembaran Negara Republik Indonesia Tahun 1999 Nomor 165, Tambahan Lembaran Negara Republik Indonesia Nomor 3886).

Undang-Undang Nomor 16 Tahun 2004 tentang Kejaksaan Republik Indonesia (Lembaran Negara Republik Indonesia Tahun 2004 Nomor 67, Tambahan Lembaran Negara Republik Indonesia Nomor 4401).

Undang-Undang Republik Indonesia Nomor 8 Tahun 1981 tentang Hukum Acara Pidana (KUHAP) (Lembaran Negara Republik Indonesia Tahun 1981 Nomor 76, Tambahan Lembaran Negara Republik Indonesia Nomor 3209). 
Peraturan Pemerintah Republik Indonesia Nomor 75 Tahun 2019 tentang Peraturan Pelaksanaan Undang-Undang Nomor 3 Tahun 2017 tentang Sistem Perbukuan. (Lembaran Negara Republik Indonesia Tahun 2019 Nomor 193, Tambahan Lembaran Negara Republik Indonesia Nomor 6408).

Peraturan Mahkamah Konstitusi Nomor 6/PMK/2005 tentang Pedoman Beracara Dalam Perkara Pengujian Undang-Undang. 
